\title{
P-Selectin Glycoprotein Ligand 1
}

National Cancer Institute

\section{Source}

National Cancer Institute. P-Selectin Glycoprotein Ligand 1. NCI Thesaurus. Code C128478.

P-selectin glycoprotein ligand 1 (412 aa, $\sim 43 \mathrm{kDa}$ ) is encoded by the human SELPLG gene. This protein is involved in the modulation of rolling and cell adhesion in circulating leukocytes. 